\title{
Socio-economic impact of CSR activities of an Islamic Banking: A Case of Islami Bank Bangladesh Limited
}

\author{
Syeda Tanjila Shahnewaz \\ Lecturer in Finance, Southeast University, Dhaka, BANGLADESH \\ E-mail for correspondence: syeda.tanjila@yahoo.com
}

DOI: https://doi.org/10.18034/abr.v6i3.41

\begin{abstract}
This paper examines the practices and driving philosophy of corporate social responsibility (CSR) by Islami Bank in Bangladesh and to evaluate the need to modify CSR program of the organization to enhance its effectiveness. The purpose of the paper is to study the underlying drivers of the CSR program undertaken by the Islami Bank Bangladesh Limited and to explore if the CSR activities are planned as a holistic approach to social development. This study covers a period of 5 years ranging from 2010 - 2014 using secondary data from annual reports of the bank, relevant articles, websites, Bangladesh Bank publications, newspaper, journal and magazines. This study found that the Islami Bank Bangladesh had linked its CSR program as core business strategy to grow business with shared prosperity with its surrounding community. However, it has the improvement opportunity to create a synergy by bundling all its CSR activities as a holistic program. If appropriately planned, such program will promote self-sufficiency, create new jobs and enable economic development under alternative livelihood program as suitable in the locality.
\end{abstract}

\section{JEL Classifications: M 14}

Keywords: Corporate social responsibility, Islami Bank Bangladesh Limited, CSR program, Social impact

\section{INTRODUCTION}

The philosophy of Corporate Social Responsibility (CSR) relies on the idea that Government should not bear the sole responsibility to contribute to the wellbeing of the society, rather companies also have aresponsibility to work for the benefit of the community in which it operates. The term CSR suggests that companies should voluntarily include societaland environmental concerns into their business strategyand into their interaction with their stakeholders including the immediate community. The essence of CSR is on focusing on voluntary activities rather than merely complying with local rules and laws. In some region, laws might be inadequate to address some grave concerns like Green House gas emission, deforestation, labor welfare, etc. However, Corporate responsibility voluntarily takes care of such issues in more delicacy beyond regulatory requirements to uphold their corporate values and ethics. In this evolution, their responsibility has gone beyond their physical perimeter and has grown into the surrounding communities to cater their various needs like economic development, education, health, nutrition, skill development, etc. In fact, over the last few decades, corporations in the developed countries have moved from classical 'Profit Maximizing Approach' to 'Social Responsibility Approach' where the business entities are primarily accountable to the owners, butalso indirectly responsibleto the society as a whole from a broader perspective. From this view, a socially responsible company is expected to take more voluntary efforts beyond merely complying with the legal and regulatory requirements.

In Bangladesh, the banking sector has a relatively prominent history of getting engaged themselves in different kinds of social activities like donations to various charitable organizations, sponsoring government initiatives on various significant occasions, patronizing cultural events, providing aids to the distress people during calamities, etc. In recent times, such activities have gained tremendous pace thanks to a Bangladesh Bank Guideline issued in 2008 suggesting the Banks to conduct and manage such activities in a more systemic approach rather than as an ad-hoc and contingent program. 
It is interesting to see how banks that conduct Islamic banking perceive their CSR responsibility. As Islam is based on the principles of the equal right of individuals as well as sharing benefits with the society, banks that follow the Islamic values should have paramount responsibility to be involved in social activities. Since Islami Bank Bangladesh Limited is the largest Islamic bank in Bangladesh, we like to focus on their CSR program to understand this issue.

\section{ObJectives OF THE STUdy}

This paper primarily focuses on the CSR activities of IBBL to identify the rationale or philosophy behind CSR program, to explore the existence of any systemic approach and to provide a set of recommendations for the improvement of the CSR activities of Islami Bank Bangladesh Limited. Hence, this research has taken following steps in sequence to complete the study -

- Identify the major CSR activities performed by Islami Bank Bangladesh Limited.

- Examine the performance of CSR activities of Islami Bank Bangladesh Limited to identify improvement opportunities in their CSR program

- $\quad$ Recommend remedial measures for the development of a systemic CSR program for Islami Bank Bangladesh Limited.

\section{LITERATURE REVIEW}

This study started with reviewing existing work that already touches some general areas where purpose of CSR, its effect on brand value, impact on consumer acceptance, benefits to the corporation and implicit attributes have been examined. This literature survey has set stage to further understand the influence of the program on the direct beneficiary and its long-term sustainability.

The concept of CSR first emerged in 1950 by Bowen. After its emergence, the meaning and aspects of CSR have evolved over the decades and many researchers and Institutions has tried to define CSR from dynamic perspective or context. For example, Backman (1975) identified CSR activities as: "employment of minority groups, reduction of pollution, greater participation in programs to improve the community, improved medical care, improved industrial health and safety etc. that are designed to improve the quality of life are covered by the broad umbrella of social responsibility". Later, European Commission (2002) defines CSR as a concept whereby companies integrate social and environmental concern in their business operations and interaction with their stakeholders on a voluntary basis. Archie B. Carroll (1979) defined the purview of CSR to encompass the economic, legal, ethical and discretionary (philanthropic) expectations of the society from the business organizations in order of priority at a given point in time.
Maignan and Ralston (2002) viewed corporate social responsibility as a medium to enhance firms' acceptance in the eyes of their stakeholders and to develop favorable images. In recent times social responsibility usually refers to the strategic goals that should be included in the business simultaneously with the economic performance (e.g., profits) goals. We can take an example of banking industry. Across the globe, its stakeholders including shareholders, investors, media, NGOs and customers have been heavily scrutinizing the business ethics and responsibility in its mode of operation (Du, S. Bhattacharya, C.B. Sen, S. 2010). Wise and Ali (2009) showed CSR as an evolving framework for corporate executives within which to formulate and administer corporate policies to support organization's strategy and to meet the requirement of its stakeholders.

The philosophy of CSR in Islam is very broad that is strongly founded on taqwa (mindful of God in all action) by which corporation also assumes its roles and responsibility as servants of God in all situations (Dusuki, A.W. and Dar, H, 2005). Accounting and Auditing Organization for Islamic Financial Institutions (AAOIFI) expressed their view on Corporate Social Responsibility (CSR) for IFIs that all their activities should fulfill its religious, economic, legal, and ethical standards and should discharge its discretionary responsibilities as financial intermediaries for individuals and institutions. In this instance, concerned management should honor all the principles of Islam regarding business activity.

Following the global trend, CSR is also gradually making its way in the corporate culture of Bangladesh even though this item still remains as one of the major ethical dilemmas for business executives of the financial sectors which are relatively ahead in corporate governance due to the ambivalent consequence of corrupt corporate practice in Bangladesh. Nonetheless, the role of CRS is getting clearer over time with the establishment of CSR center in Bangladesh. The expectations from CSR was well echoed in the launching remark of the CEO of CSR center in Bangladesh that CSR goes beyond philanthropy and is a comprehensive strategy to link core business strategy to the issues of environment, human rights and labor welfare, good governance and sustainable social investment measures (Shahamin S. Zaman, CEO, BCSR Center).

The underlying business rationale or operating principles guiding CSR activities in the Islamic finance sector in Bangladesh can be widely different from generally understood principles by early researchers. To explore any existence of such gap between Islamic finance sector and other non-Islamic corporations, this study also undertook some literature reviews to understand few fundamental reasons to undertake CSR program by nonIslamic organizations. Corporations are found motivated to conduct CSR to increase market share and brand image due to the belief that most of the buyer prefers products of 
socially responsible firms over others and are willing to switch their brands accordingly (Maignan, Ferrell, and Hult, 1999). Another survey in the USA showed that almost $43 \%$ customers displayed their positive impression by the information of donations made for social welfare and development activities byfirms (Hess, D. and Rogovsky, N. Dunfee, T.W. 2002). McWilliams and Siegel (2001) indicated that business entities practicing true CSR activities increase their profitability by boosting their image and develop the competitive advantage in the long run.

\section{Methodology of the Study}

This study is exclusively a descriptive research, and thus it is purely based on the information from secondary data sources. Relevant articles, magazines, books, journals, various newspapers, relevant online academic resources, research documents and literature related to CSR have been reviewed. Furthermore, the contextual data were collected through personal interviews of designated representative of the bank and from various published sources - for example, annual reports of the bank, Bangladesh Bank publications, and websites of IBBL. In this paper, different data of IBBL during the period 20102014 have been analyzed to develop insights on the topic.

\section{ANALYSIS AND FINDINGS}

This study examined Corporate Social Responsibility Report (CSR) of IBBL to compare relative position of IBBL against overall Banking Industry in Bangladesh regarding CSR expenditure and also identified the strategic element in the overall contribution of IBBL to the sustainable development of the community. The Bank was found very much conscious about its responsibility towards the community. The essence of such expectation is reflected in the mission of the Bank since the day of establishment:

"To establish Islamic Banking through an introduction of a welfare oriented banking system ensuring equity and justice in all economic activities and achieve balanced growth and equitable development through diversified investment operations particularly in the priority sectors and less developed areas of the country. To encourage socio-economic uplift and financial services to the low-income community particularly in the rural areas."

The Bank is also well aware of its responsibility inside organization before it reaches out its external stakeholders and communities. It upholds human rights at every level of its operations. IBBL does not employ workers under the minimum legal age, prohibits the use of forced labor, honors employees' rights to participate or to form a labor union, respects the principles of collective bargaining, and ensures healthy \& safe workplace. The Bank does not make any discrimination by age, gender, race or socioeconomic condition. It limits its business operation to standard accepted hours and denounces any sorts of abuse of its workforce in any form. However, this study finds that IBBL's mission statement misses to touch these internal elements, and remained heavily outward looking.

Nonetheless, based on strong ethical foothold on its deeply ingrained caring attitude towards internal stakeholder, it extends its responsibility towards external stakeholder too with bold steps. As one of the biggest Islamic Bank of the world and one of the best corporate body of the country, Islami Bank Bangladesh Limited has been demonstrating its firm commitment to its external stakeholders, employees, and customers alike. It focuses its activities mostly in individual and organizational level for the development of the community especially in the less fortunate segments of the community.

This study briefly covers the history of CSR program in IBBL to understand the focus-area and modality of its CSR program. To popularize the concept of Islamic Banking a welfare oriented Banking system, Islami Bank Bangladesh Limited had started its charitable activities since inception through the creation of "Sadaqah Tahbil". Afterwards, it was carried out through Islami Bank Foundation after conversion of the Sadaqah Tahbil into a full-fledged foundation since May 20, 1991. Subsequently, it has been discharging its responsibilities to the society in general directly through its banking activities and also through its fully owned subsidiary, Islami Bank Foundation (IBF). Further to its campaign under IBF, "Islami Bank Bangladesh Ltd." established Corporate Social Affairs Department (CSAD) under Operations Wing on 16th July 2009 in compliance with the instruction of the Central Bank.

The CSAD is responsible for developing and proposing Annual CSR Plan with budgetary allocations to the board of directors for approval. The board approves the proposed allocations by appropriating fund from the annual post-tax net profits. Around 30\% share of total CSR expenditure is usually allocated for educational program and $20 \%$ for healthcare program. If post-tax net profit becomes unavailable in some year, the bank has the freedom to postpone committing for new CSR program expenditure but usually continues previous CSR commitments like scholarship program.

CSR program in IBBL was conducted both as occasional remedial measures and as sustainable continuous projects. This study found their CSR program mostly structured to address few key sectors; such as (1) Education, (2) Health, (3) Humanitarian \& Disaster Relief and (4) Sports, arts \& culture.

The following table summarizes their sector-wise spending over few years for easy comparison.

This study explores and provides a brief snapshot of the nature of spending in each of this item to identify whether the management of the organization follows any pattern in CSR spending. 
Sector wise CSR expenditure of IBBL from 1983-2014 (Figure in million)

\begin{tabular}{|c|c|c|c|c|c|c|c|c|c|c|c|c|}
\hline \multirow[b]{2}{*}{ Sector } & \multicolumn{2}{|c|}{ 1983-2010 } & \multicolumn{2}{|c|}{2011} & \multicolumn{2}{|c|}{2012} & \multicolumn{2}{|c|}{2013} & \multicolumn{2}{|c|}{2014} & \multicolumn{2}{|c|}{ Total } \\
\hline & Amount & $\begin{array}{l}\text { No. of } \\
\text { Benefi } \\
\text { ciaries }\end{array}$ & Amount & $\begin{array}{l}\text { No. of } \\
\text { Benefi } \\
\text { ciaries }\end{array}$ & Amount & $\begin{array}{l}\text { No. of } \\
\text { Benefi } \\
\text { ciaries }\end{array}$ & Amount & $\begin{array}{l}\text { No. of } \\
\text { Benefi } \\
\text { ciaries }\end{array}$ & Amount & $\begin{array}{l}\text { No. of } \\
\text { Benefi } \\
\text { ciaries }\end{array}$ & Amount & $\begin{array}{l}\text { No. of } \\
\text { Benefi } \\
\text { ciaries }\end{array}$ \\
\hline Education & 353.14 & 363,984 & 56.17 & 128,925 & 83.8 & 3014 & 135.26 & 7,756 & 161.34 & 7928 & 789.71 & 511,607 \\
\hline Health & 937.73 & $6,776,641$ & 25.78 & 128,556 & 39.75 & 19,230 & 71.50 & 95,255 & 89.47 & 125079 & 1164.23 & $7,144,761$ \\
\hline $\begin{array}{l}\text { Humanitarian \& } \\
\text { Disaster Relief }\end{array}$ & 281.67 & 611,051 & 21.79 & 32,928 & 87.93 & 597866 & 140.10 & 254078 & 190.16 & 498768 & 721.65 & $1,994,691$ \\
\hline Sports & 72.83 & 413,624 & 248.75 & 636 & 1.61 & 144 & 78.97 & 7 & 40.2 & 5 & 442.36 & 414,416 \\
\hline Arts \& Culture & 79.97 & 229,071 & 7.15 & 643 & 8.24 & 11 & 5.86 & 21 & 15.21 & 17 & 116.43 & 229,763 \\
\hline Environn & 7.36 & 15,240 & 0.48 & 3 & 12.48 & 493,822 & 22.94 & 592722 & 21.12 & 723673 & 64.38 & $1,825,460$ \\
\hline Others & 73.18 & 57,329 & 50.55 & 118,115 & 75.38 & 34438 & 21.79 & 768 & 7.02 & 51 & 227.92 & \begin{tabular}{|l|}
210,701 \\
\end{tabular} \\
\hline Total & $1,805.88$ & $8,466,940$ & 410.67 & 409,806 & 309.19 & $11,48,525$ & 476.42 & 950,607 & 524.52 & $1,355,521$ & 3526.68 & $12,331,399$ \\
\hline
\end{tabular}

\section{Education}

IBBL started focusing on the education sector of the country from its very beginning of CSR program. It started several scholarship program and financial assistance programs to the educational institutions involved in technology development, research organizations, and publications. IBBL's annual scholarship program covers eight hundred students combined from HSC and SSC to support their academic life in the next steps and another four hundred students in other educational institutions for the tenure of their courses. It also aids in the establishment of infrastructure or operations of auxiliary educational facilities for example libraries, informal community classes, computers, science laboratories, etc. IBBL spent an amount of Tk. 789.71million for 511,607 beneficiaries from 1983-2014 for this purpose.

\section{Support to the physically-challenged children}

The management of IBBL clearly demonstrates their belief that the physically-challenged children are not liabilities, rather the asset of the society if they can be nurtured properly along with a proper support infrastructure for them. Their belief has been translated through CSR program targeting for the well-being of such children with special needs and disability. To effectively manage this program, IBBL has partnered with a specialized organization in this field named 'PROYASH'- an organization run under the patronization of Bangladesh Army to help these special children in need.

\section{Health Program}

The next focus of IBBL's CSR program is on Health sector which is also a basic need of all societies. IBBL spends an amount of Tk. 1164.23 million for 7,144,761 beneficiaries from 1983-2014 to run several health-care program in individual and organizational level across the country. Under this program, IBBL established 8 (eight) fully owned hospitals and 7 (seven) community hospitals to provide affordable health service to the community and also creates employment. Besides, it also conducts several supplementary campaigns to provide specialized health services, for example, Charitable Dispensaries, Arsenic Mitigation Program, Circumcision Camp, Mobile Eye
Camp and Midwifery Training Program, etc. for bringing the quality health service at the door of the marginal community of the country.

\section{Sports, Arts \& Cultural Program}

In addition to its contribution to the basic needs of the community, IBBL also takes part in the creative and entertainment arena of the country. To build nation's positive image, it very often sponsors various sports \& cultural events every year. It endeavors to protect and preserve national heritage and originality of indigenous art and culture of the society by contributing to the restoration work of building and sites of historical interest and renowned artworks. It also promotes and develops traditional arts and handicrafts, rural and nationally recognized sports and games. IBBL spent an amount of Tk. 558.79 million from 1983-2014 for this purpose.

\section{Protecting Environment}

IBBL heavily weighs the threat of natural disaster in Bangladesh due to its location in southern delta. Hence, it focuses on several initiatives under CSR program to protect the environment. Its effort includes reducing carbon emission through the installation of solar panels, introducing various measures for saving consumption of electricity, water, gas, and fuel, encouraging double-sided printing to reduce paper usage, promoting the use of recycled/scrap/one-side-used papers for note-pad, etc. IBBL invested an amount of Tk. 64.38 million during 19832014 tenure for all such activities under CSR program to protect environment benefiting about two million people.

\section{Human Resource Development}

IBBL believes in the improvement of people's standard of living as a measure of the economic development of a nation. Since the standard of living is directly linked to income level which is further dependent on economic productivity of the individuals driven by their skillset, IBBL has a strong focus on human resource development to contribute to the personal development of the community it works with. IBBL has so far established a medical college, a health technology institute, a nursing training institute, few schools both in English\& Bengali as medium of education, a girl's madrassa and six (6) 
technical institutions. In this way, it contributed to the development of human resources of the country, thereby, complementing towards economic development of the country.

\section{Humanitarian causes}

While we see that CSR program of IBBL is heavily focused on the systematic development of the community as evident from above discussion, it does not shy away to contribute to humanitarian causes when such necessity arises. In fact, displaying highest standards of corporate citizenship, IBBL always stands beside the distressed people in need. It provides disaster relief to the affected community in any natural calamity, distributes winter clothes to the poor, makes the donation to the PM's relief fund, and conducts rehabilitation program for the victims of natural disaster. IBBL also discharges its responsibilities towards the poor and less privileged segments of the society by devising special deposit products to broaden the coverage of financial service and by providing financial assistance. Being driven by Islamic philosophy, IBBL also engages in humanitarian work during religious occasions to support the poor. For example, it conducts a unique program named "Tohfa-e-Ramadan" that provided food items to 40,000 underprivileged families including the poor religious scholars worth of Tk. 63.08 million during last Ramadan. It also distributed the sacrificial meat among the poor during Eid ul Adha. IBBL spent an amount of Tk. 721.65 million from 1983-2014 covering about two million vulnerable people.

From the discussion above, this study found that CSR program of IBBL mostly focuses on education and health sector as a primary driver for social development followed by investments in Human resource development through skill training in various trade and craftsmanship, however, misses opportunity to further contribute to promoting self-sufficiency, priming job creation, and economic development. While IBBL is conducting several humanitarian programs to address the financial condition of distressed people, those entire programs were found as stand-alone activities or ad-hoc emergency response rather than a strategic development program for the sustainable elevation of living standard as this study could not find any linkage between this program. No database was found that could identify common beneficiaries of various CSR program. Many households may have numerous combinations of needs of assistance in education, health, trades, skill training, or finances for livelihoods, etc. No effort was found to identify such blend of necessities for a household to design and plan for holistic CSR program to create a long-lasting impact on their living standards. For example, the scholarship program was not found actively tracking the records of the continuation of studies of their beneficiary students even though pre-mature school dropping due to economic hardship is a well-known development concern in Bangladesh. Similarly, serious health issues may disrupt studies of a promising student who was thriving for the sustainable improvement of living standards for the whole family through education. Similar combinations of necessity can be explored in many dimensions once initiatives are taken to understand those needs in the community. IBBL management did not take the initiative or additional effort to design a holistic CSR program that bundles necessary pieces of different CSR campaigns to cater the specific needs of respective communities.

\section{CSR POSITION OF IBBL IN THE BANKING SECTOR OF BANGLADESH}

Islami Bank Bangladesh Limited is the biggest private commercial Bank of Bangladesh. Banking Industry of Bangladesh consists of more than 50 Banks from the private \& public sector. An amount of Tk. 2329.80, 2188.33 \& 3046.69 million was spent by all Banks of Bangladesh for CSR activities during the year 2010, 2011 \& 2012 respectively. Contribution of IBBL was $10 \%$ in $2010,19 \%$ in 2011, 10\% in 2012 and 11\% in 2013.

In our comparative discussion, the quality of Corporate Social Responsibility was assessed as the commitment of bank management in various commercial activities to contribute to sustainable development. The commitment was reflected in the working with their employees, their families, local communities and the society as a whole. All these activities helped to upgrade the people's living standards in a certain way that served commerce and development at the same time.

\section{Recommendation ANd Conclusion}

To conclude, the concept of CSR is not alien to Islam, for it is deeply inscribed in the Shariah. Therefore, the philosophy of CSR for Islamic corporations is very different from the western philosophy of CSR program. Hence, being a socially responsible and Shari'ah compliant organization, Islami Bank Bangladesh Limited has broad coverage in CSR activities which has a significant contribution to the overall socio-economic development of the general people of Bangladesh.

Corporate organizations can conduct social and benevolent activities under CSR program for enhancing balanced socio-economic development. Literature survey under this study has found out that the acceptance of Corporate Social Responsibility is growing day by day in Bangladesh and has become a criterion of socially acceptable business endeavour. This study has found that CSR activities in Islami Bank Bangladesh have linked CSR program as core business strategy to growth driven by Islamic belief of shared prosperity which is evident both from their mission statement and from the pattern of CSR program.

From this study, it is also very clear that CSR activities have a high contribution for individuals on different dimensions to make an impact on the social or national scale. However, many of these initiatives under CSR program are not intertwined to provide holistic support 
towards family/household as a unit of beneficiaryfor sustainable economic development. Rather, it mostly remained as a number of discrete sectorial programs for communities. Hence, the impact of various CSR program could not be amplified many-fold by the potential synergy it could create through the well-strategized holistic plan to foster economic stability and improve the quality of life.

This study recommends undertaking few alternative livelihood programs by assessing local needs to generate the long-lasting impact of their CSR program. For example, it could provide a community with a soft loan or economic aid to start a mini-farm, cattle and poultry raising or fish farming, or to modernize land farming, etc. It can also provide direct consultation service on logistics or marketing techniques for their local harvest. It can help remove barriers to productive activity by providing one or several marketing channels to generate demand for their product. Such activity can significantly eradicate poverty permanently and can boost up the impact of investment in education sector further due to the reduction of school dropping of vulnerable children for economic hardship of their parents. Nonetheless, the relative contribution of IBBL is significantly better than other banks in the country. Similarly, management of the bank should be aware of synergy effect of the holistic program to design their CSR plan to drive scalable and sustainable impact in the communities.

This study also found that robust execution strategy is required to create the highest impact of the CSR plan. IBBL showed good consideration in implementation by partnering with NGOs or other development organization to leverage local expertise and resource to execute the CSR program. This study further recommends considering appropriate partnership opportunity with suitable entities like the local government body, semi-government agencies, opinion leaders, self-motivated local individuals, and unorganized local experts, etc. for conducting the CSR program that can generate deeper impact with lesser effort and resource.

\section{LIMITATIONS OF THE STUDY}

This study envisages following limitations arising from perceived lack of adequate interactions for cross verifications:

- On few occasions during interviews, respondents did not provide adequate information to supplement publicly available information for the study mostly on the ground of data confidentiality.

- Bank Representative could not review or make comments on the findings of this paper for their busy schedule; therefore, this paper could not incorporate their insights.

- This researcher did not receive adequate professional support from the industry experts required to conclude this study comprehensively.
- This paper focuses on a single Islamic bank of Bangladesh and does not intend to generalize findings for the sub-sectors of Islamic Banks in Bangladesh.

\section{REFERENCES}

Backman, J (1975), "Social responsibility and accountability", New York University Press, New York.

Carroll, A. B. (1979), “A three-dimensional conceptual model of corporate social Performance", journal of Academy of Management Review, Vol. 4, No. 2, pp 497-505. Publisher Academy of management.

Commission of the European Communities, "Communication from the commission concerning Corporate Social Responsibility: A business contribution to Sustainable Development", Brussels, $2^{\text {nd }}$ July 2002. COM (2002) 347 final.

Du, S. Bhattacharya, C. B. Sen, S. (2010), “Maximizing Business returns to corporate social responsibility (CSR): The role of CSR communication", International Journal of Management Reviews, Volume-12, Issue-1, Pages-8-19.PublisherBlackwell Publishing Ltd.

Dusuki, A. W. and Dar, H. (2005), "Stakeholders' Perception of Corporate Social Responsibility of Islamic Bank: Evidence from Malaysia Economy", Proceeding the sixth international conference on Islamic Economics, Jakarta Indonesia on 21-24n November 2005.

Hess, D. and Rogovsky, N. Dunfee, T. W. (2002), “The Next Wave of Corporate Community Involvement: Corporate Social Initiatives", California Management Review, Vol. 44 No. 2, pp110-125DOI: $10.2307 / 41166125$

Islami Bank Bangladesh Limited (IBBL) (2014) Annual Report 2014, IBBL, Dhaka.

Maignan, I. and Ralston, D. (2002), “ Corporate Social Responsibility in Europe and the U.S.: Insights from Businesses' Self-presentations", Journal of International Business Studies, Volume 33, Number 3, issue 1, pp. 497514(18)

Maignan, I. Ferrell, O. C. Hult, T. M. (1999), “Corporate citizenship: cultural antecedents and business benefits", Journal of academy Marketing Science, Volume-27, Issue-4, Pages 455-469.

McWilliams, A. and Siegel, D. (2001), "Corporate Social Responsibility: A Theory of the Firm Perspective", The Academy of Management Review, Vol. 26, No. 1, pp. 117-127. Published by: Academy of Management

Wise, V. and Ali, M.M (2009), "Corporate Governance and Corporate Social Responsibility in Bangladesh with special reference to Commercial Banks" American International University Bangladesh, Working Paper Series, No 2009.05.

www.bangladesh-bank.org,website of Bangladesh Bank (BB), cited on May 25, 2011.

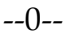

